\title{
ANALISIS NILAI-NILAI EDUKATIF DALAM NOVEL "LOVE IN PESANTREN" SEBAGAI REFORMULASI POLA INTERAKSI GURU DAN MURID DI PESANTREN
}

\author{
Achmat Mubarok, Asrul Anan \\ achmatmubarok@gmail.com, asrulanan@yudharta.ac.id \\ Universitas Yudharta Pasuruan
}

\begin{abstract}
Teacher and student interaction is very important in supporting educational success. A good pattern of interaction between teacher and student will create an educational and enjoyable atmosphere. One of the novels by Shachree M. Daroini entitled "Love In Pesantren" is a story of life in pesantren with various patterns of interaction between teacher and student. The educational values contained in the novel "Love In Pesantren" are: the value of faith and devotion, help, enthusiasm to carry out religious rituals, realize self-limitation, be able to accept change, amuse you, self-reliance, the principle of justice, respect and respect fellow human beings, think critically about life, forgive. Things that are less relevant in the pattern of interaction between teachers and students in the pesantren in the novel "Love In Pesantren", among others: giving physical punishment beyond the level of ability, attitude that is not loving, does not respect students, treats students as they wish, does not give opportunity for students to defend themselves, not humanize students, authoritarian attitudes, rely on critical reasoning on the basis of keta'dziman. While the pattern of interaction between teachers and students as a reformulation of interaction in Islamic boarding schools by increasing faith and devotion, gives a great deal of ritual diversity, mutual respect between teachers and students, respect for differences, principles of justice, forgiveness, not feeling right, and mutually open.
\end{abstract}

Keywords: Educative Value, Reformulation, Interaction Patterns.

\section{PENDAHULUAN}

Pendidikan pada hakikatnya adalah usaha sadar untuk mengembangkan kepribadian dan kemampuan di dalam dan di luar sekolah dan berlangsung seumur hidup. ${ }^{1}$ Dalam undang-undang sistem pendidikan

\footnotetext{
${ }^{1}$ Fuad Ihsan. 2003. Dasar-dasar Kependidikan. ( Jakarta: PT Rineka Cipta). Hal 2-4
} 
nasional No 20 tahun 2003 disebutkan bahwa pendidikan nasional berfungsi mengembangkan kemampuan dan membentuk watak serta peradaban bangsa yang bermartabat dalam rangka mencerdaskan kehidupan bangsa, bertujuan untuk berkembangnya potensi peserta didik agar menjadi manusia yang beriman dan bertakwa kepada Tuhan Yang Maha Esa, berakhlak mulia, sehat, berilmu, cakap, kreatif , dan menjadi warga negara yang demokratis serta bertanggung jawab. ${ }^{2}$

Pesantren sebagai salah satu lembaga pendidikan Islam, memiliki potensi dan peluang yang positif dalam membantu mengembangkan potensi dasar manusia berupa pengembangan ahlak dan akalnya. Pesantren merupakan salah satu jenis pendidikan Islam di Indonesia yang bersifat tradisional untuk mendalami agama Islam, dan mengamalkannya sebagai pedoman hidup keseharian, dengan menekankan pentingnya moral dalam hidup bermasyarakat. Kehadiran pendidikan pesantren mempunyai peranan tersendiri, bahkan menurut Mukti Ali tidak sedikit dari pemimpin bangsa yang dilahirkan dari halaqah pendidikan di pesantren. Hal ini menurut Naufal Ramzy karena jika dilihat dari spektrum pembangunan bangsa, pondok pesantren disamping menjadi lembaga pendidikan Islam, juga sebagai bagian dari infrastruktur masyarakat yang secara sosiokultural ikut berkiprah dalam proses pembentukan kesadaran masyarakat untuk memiliki idealisme demi kemajuan bangsa dan negaranya. ${ }^{3}$

Di Indonesia istilah pesantren lebih popular dengan sebutan pondok pesantren. Lain halnya dengan pesantren, pondok berasal dari bahasa Arab funduq, yang berarti hotel, asrama, rumah, dan tempat tinggal sederhana. ${ }^{4} \mathrm{Di}$ pesantren terdiri dari lima elemen pokok, yaitu: kyai, santri, masjid, pondok, dan pengajaran kitab-kitab islam klasik. Pondok pesantren juga disatukan melalui persamaan tata hubungan yang khas dalam kependidikan dan kemasyarakatan, yaitu: 1) hubungan yang dekat antara kyai dan santri; 2) ketaatan santri yang tinggi kepada kyai; 3) hidup hemat dan sederhana; 4) tingginya semangat kemandirian para santri; 5) berkembangnya suasana

\footnotetext{
2 Undang-Undang Republik Indonesia No.20 Tahun 2003 tentang Sistem Pendidikan Nasional (SISDIKNAS).

3 Mansur. 2004. Moralitas Pesantren: Meneguk Kearifan dari Telaga Kehidupan. (Yogyakarta: Safiria Insania Press). Hal 7-8

${ }^{4}$ Yasmadi. 2002. Modernisasi Pesantren: Kritik Nurcholis Madjid Terhadap Pendidikan Islam Tradisional. (Jakarta: Ciputat Press). Hal 62
} 
persaudaraan dan tolong menolong; 6) kuatnya semangat mencapai cita-cita; 7) tertanamnya sikap disiplin dan istiqomah. ${ }^{5}$

Dari salah satu penjelasan dari tata hubungan kependidikan dan kemasyarakatan di atas, bahwa santri dan kyai perlu memiliki hubungan yang dekat. Keberadaan kyai dalam lingkungan pesantren laksana jantung bagi kehidupan manusia. Intensitas kyai memperlihatkan peran yang otoriter disebabkan karena kyailah perintis, pendiri, pengelola, pengasuh, pemimpin, dan bahkan juga pemilik tunggal sebuah pesantren. Hubungan pemimpin pesantren dengan para santrinya tampaknya tidak hanya terbatas pada hubungan antara guru dan murid belaka, akan tetapi, lebih dari itu yaitu hubungan timbal balik dimana santri menganggap kyainya sebagai bapaknya sendiri, sementara itu kyai menganggap santrinya sebagai titipan Tuhan yang senantiasa harus dilindungi (hubungan antara orang tua dan anak). ${ }^{6}$

Peranan kyai sebagai guru tentunya sebagai tempat bertanya. Kemudian, peranannya sebagai orang tua, kyai merupakan tempat di mana santri mengadu, terutama jika santri mempunyai masalah yang tidak dapat dipecahkan sendiri. Kedudukan kyai sebagai orang tua yang dianggap dapat memecahkan masalah secara bijak tampaknya tidak hanya menyangkut masalah santri sebagai individu, tetapi juga masalah yang terjadi antar santri. ${ }^{7}$

Namun, seiring dengan semakin bertambahnya jumlah santri dalam sebuah pesantren, kyai tidak bisa berdiri sendiri untuk mengayomi seluruh santri. Oleh karena itu, kyai banyak dibantu oleh para guru (ustadz dan ustadzah) dalam menggerakkan roda pendidikan dan pengajaran di pesantren. Guru dan murid yang terlibat dalam pendidikan sekolah, dimana sekolah itu sendiri menjadi otoritas pesantren. Guru yang dimaksud disini adalah sosok yang digugu lan ditiru, dimana seorang guru menjadi contoh yang baik bagi muridnya melalui sebuah interaksi sesuai dengan norma agama dan negara.

Istilah interaksi, sebagaimana telah banyak diketahui orang, adalah suatu hubungan timbal balik antara orang satu dengan orang lainnya. Di dalam sosiologi misalnya, interaksi selalu dikaitkan dengan istilah interaksi sosial, yaitu hubungan timbal balik atau aksi dan reaksi diantara orang-orang.

\footnotetext{
${ }^{5}$ Departemen Agama RI Direktorat Jenderal Kelembagaan Agama Islam. 2003. Pondok Pesantren dan Madrasah Diniyah Pertumbuhan dan Perkembangannya. (Jakarta: Departemen Agama RI). Hal 29

${ }^{6}$ Departemen Agama RI Direktorat Jenderal Kelembagaan Agama Islam. Pondok Pesantren dan Madrasah Diniyah Pertumbuhan dan Perkembangannya. (Jakarta: Departemen Agama RI) Hal 63

${ }^{7}$ Ibid. Hal 64
} 
Yang mana interaksi sosial tidak memperdulikan hubungan tersebut bersifat bersahabat atau bermusuhan, dilakukan berhadapan atau tidak, yang penting dalam interkasi ini adalah kontak dan komunikasi di antara orang-orang itu. Akan tetapi berbeda dengan interaksi ini dihubungkan dengan proses belajar mengajar. Di dalam interaksi belajar mengajar, timbal balik antara guru (pendidik) dan murid (anak didik) harus menunjukkan adanya hubungan yang bersifat edukatif (mendidik), hal mana interaksi itu harus diarahkan pada pada suatu tujuan tertentu yang bersifat mendidik yaitu adanya perubahan tingkah laku anak didik kearah kedewasaan. ${ }^{8}$

Di dalam interaksi tugas guru tidaklah terbatas pada sekedar menyampaikan materi kepada anak didik, akan tetapi lebih dari itu adalah, bahwa seorang guru harus berusaha membimbing anak didiknya. Kesulitankesulitan dan hambatan siswa dalam belajar hendaklah merupakan tantangan bagi guru untuk berusaha membantu memecahkannya. ${ }^{9}$

Interaksi guru dan murid merupakan hal yang vital dalam mendukung keberhasilan pendidikan. Pola interaksi guru dan murid yang baik, akan menciptakan suasana belajar yang edukatif dan menyenangkan. Sebaliknya, pola interaksi yang terlampau formal menyebabkan kerenggangan hubungan antara guru-murid yang berdampak pada suasana belajar yang cenderung menegangkan dan kaku. Sehingga, dapat dikatakan bahwa dalam interaksi guru dan murid inilah terjadi proses edukasi dan sosialisasi, contohnya pendidik yang kurang akrab dengan peserta didiknya, sehingga pendidik tidak bisa mengetahui perubahan pada peserta didiknya yang akan mengakibatkan kekakuan dalam berkomunikasi antara peserta didik dan pendidik.

Salah satu novel karya anak bangsa yang bernama Shachree M. Daroini dengan judul "Love In Pesantren" merupakan cerita kehidupan di pesantren dengan berbagai pola interaksi antara guru dan murid yang perlu dikaji secara teoritis, diteliti dan dianalisis tentang nilai-nilai edukatif yang terdapat didalamnya, pola interaksi yang ada antara guru dan murid, dan juga formulasi pola interaksi di dunia pesantren.

Berdasarkan uraian diskripsi pendahuluan di atas, peneliti tertarik untuk melakuakn kajian, dan melakukan telaah, serta menganalisis kandungan nilai-nilai pendidikan dalam karya sastra tersebut, pola interksi

\footnotetext{
8 Soetomo. 1993. Dasar-dasar Interaksi belajar Mengajar. (Surabaya: Usana Offset Printing). Hal 9

${ }^{9}$ Soetomo. Dasar... Hal 25
}

Jurnal al-Murabli, Volume 4 Namar 2, Juni 2019 
yang terbangun, dan juga melakukan reformulasi pola interaksi antara guru dan murid di pesantren, sehingga akan terbentuk pola interaksi yang baik antara guru dan murid.

\section{KAJIAN TEORI}

Pesantren adalah lembaga pendidikan keagamaan yang mempunyai kekhasan tersendiri dan berbeda dengan lembaga pendidikan lainnya. Pendidikan di pesantren meliputi pendidikan Islam, dakwah, pengembangan kemasyarakatan dan pendidikan lainnya yang sejenis, peserta didik di pesantren disebut santri yang umumnya menetap di pesantren. Ditinjau dari segi historisnya, pondok pesantren adalah bentuk lembaga pendididikan pribumi tertua di Indonesia. Pondok pesantren sudah dikenal sejak jauh sebelum Indonesia merdeka, bahkan sejak Islam masuk ke Indonesia terus tumbuh dan berkembang sejalan dengan perkembangan dunia pendidikan pada umumnya. Sebuah lembaga yang bernama pondok pesantren adalah suatu komunitas tersendiri, di dalamnya hidup bersama-sama dengan sejumlah orang yang komitmen hati dan keikhlasan atau kerelaan mengikat diri dengan kyai, tuan guru, buya ajengan, abu atau nama lainnya, untuk hidup bersama dengan standart moral tertentu, membentuk kultur atau budaya sendiri ${ }^{10}$.

Sebuah komunitas disebut pondok pesantren minimal ada kyai (tuan guru, buya, ajengan, abu), masjid, asrama (pondok), pengajian kitab kuning atau naskah salaf tentang ilmu-ilmu keislaman. ${ }^{11}$ Di dalam pesantren memilikiri lima elemen pokok, yaitu: kyai, santri, masjid, pondok, dan pengajaran atau pengajian kitab-kitab Islam klasik. Kelima elemen tersebut merupakan ciri khusus yang dimiliki pesantren dan membedakan pendidikan pondok pesantren dengan lembaga pendidikan dalam bentuk lain, yakni:

Pertama, Kyai sebagai salah satu unsur dominan dalam kehidupan sebuah pesantren, kyai mengatur irama perkembangan dan kelangsungan kehidupan suatu pesantren dengan keahlian, kedalaman ilmu, karismatik, dan keterampilannya. ${ }^{12}$ Kyai berfungsi sebagai sosok model atau teladan yang

10 B. Suharto, Dari Pesantren Untuk Umat: Reiventing Eksistensi Pesantren di Era globalisasi, Surabaya: IMTIYAZ. 2011

${ }^{11}$ Departemen Agama RI Direktorat Jenderal Kelembagaan Agama Islam. Pondok Pesantren dan Madrasah Diniyah Pertumbuhan dan Perkembangannya. (Jakarta: Departemen Agama RI). Hal 1-2

12 B. Suharto, Dari Pesantren Untuk Umat: Reiventing Eksistensi Pesantren di Era globalisasi, Surabaya: IMTIYAZ. 2011. Hal. 63 
baik (uswah hasanah) tidak saja bagi para santrinya, tetapi juga bagi seluruh komunitas di sekitar pesantren. Kewibawaan dan kedalaman ilmunya adalah modal utama bagi berlangsungnya semua wewenang yang dijalankan. Ia dikenal seagai tokoh kunci, kata-kata dan keputusannya dipegang teguh oleh mereka, terutama oleh para santri. Meskipun demikian kyai lebih banyak menghabiskan waktunya untuk mendidik para santrinya ketimbang hal-hal lain. $^{13}$

Kedua, Santri sebagai unsur terpenting dari sistem penddikan pesantren, menjadi fokus terpenting yang perlu diberdayakan. ${ }^{14}$ Santri terdiri dari dua kelompok: Pertama, santri mukim ialah santri yang berasal dari daerah yang jauh dan menetap dalam pondok pesantren. Kedua, santri kalong ialah santri yang berasal dari daerah-daerah sekitar pesantren dan biasanya mereka tidak menetap dalam pesantren. Semakin besar sebuah pesantren akan semakin besar jumlah santri mukimnya. Dengan kata lain pesantren kecil akan memiliki lebih banyak santri kalong dari santri mukim. ${ }^{15}$

Ketiga, Masjid sebagai pusat kegiatan ibadah dan belajar mengajar. Masjid merupakan sentral sebuah pesantren karena disinilah pada tahap awal bertumpu seluruh kegiatan di lingkungan pesantren, baik yang berkaitan dengan ibadah, sholat berjama'ah, zikir, wirid, do'a, I'tiqaf, dan juga kegiatan belajar mengajar. Perkembangan selanjutnya, seiring dengan perkembangan jumlah santri maka pelajaran berlangsung di bangku, tempat khusus, dan ruangan-ruangan khusus untuk halaqah-halaqah. Perkembangan terakhir menunjukkan adanya kelas-kelas sebagaimana terdapat pada madrasah-madrasah. ${ }^{16}$

Keempat, Pondok merupakan tempat santri mukim dengan kyai pimpinan pesantren serta anggota lainnya, biasanya tinggal dalam suatu lingkungan tersendiri. Inilah yang disebut pondok. Disinilah kyai bersama santrinya bertempat tinggal. Adanya pondok sebagai tempat tinggal bersama antara kyai dengan para santri sangat bermanfaat dalam rangka bekerja sama memenuhi kebutuhan hidup sehari-hari. Hal ini merupakan pembeda dengan lembaga pendidikan lainnya.

\footnotetext{
${ }^{13}$ Suharto, Dari.... Hal 64

14 Mansur. Moralitas Pesantren:Meneguk Kearifan dari Telaga Kehidupan. Yogyakarta: Safira Insania Press. 2014. Hal 27

15 Yasmadi. Modernisasi Pesantren: Kritik Nurcholis Madjid Terhadap Pendidikan Islam Tradisional. Jakarta: Ciputat Press. 2002 Hal 67

${ }^{16}$ Yasmadi. Modernisasi.... Hal 64
} 
Kelima, Pengajaran atau pembelajaran kita-kitab Islam klasik, dalam kaitannya dengan pondok pesantren salafiyah, ajaran adalah apa yang terdapat dalam kitab kuning, kitrab rujukan, atau referensi yang dipegang oleh pondok pesantren tersebut. Metode pembelajaran di pondok pesantren salafiyah ada yang bersifat tradisional, yaitu metode pembelajaran yang diselenggarakan menurut kebiasaan yang telah lama dilaksanakan pada pesantren atau juga disebut sebagai metode pembelajaran asli (original) pondok pesantren. Di samping itu ada pula metode pembelajaran modern (tajdid). Metode pembelajaran modern merupakan metode pembelajaran hasil pembaharuan kalangan pondok pesantren dengan memasukkan metode yang berkembang pada masyarakat modern, walaupun tidak selalu diikuti dengan menerapkan sistem modern, yaitu sistem sekolah atau madrasah. ${ }^{17}$

Memang disadari bahwa pada pesantren ada pengawasan ketat, tetapi itu hanya menyangkut tata norma atau nilai, seperti perilaku peribadatan khusus dan norma-norma muamalat tertentu. Sedangkan bimbingan dan norma belajar supaya cepat pintar dan cepat selesai, boleh dikatakan hampir tidak ada Pesantren merupakan lembaga. Jadi pendidikan pesantren itu titik tekanannya bukan pada aspek kognitif seperti pada lembaga-lembaga pendidikan modern sekarang, tetapi justru pada aspek afektif dan psikomotorik. Singkatnya bagaimana santri mau dan mampu menyadari nilainilai ajaran Islam dan menginternalisasikan pada dirinya, kemudian mau dan mampu mewujudkannya dalam perilaku dan kehidupan. ${ }^{18}$ Kehidupan di pesantren memiliki keunikan tersendiri melalui interaksi dan komunikasi atau hubungan. Dalam proses komunikasi, dikenal adanya unsure komunikan dan komunikator. Hubungan antara komunikator dengan komunikan biasanya karena menginteraksikan sesuatu, yang dikenal dengan istilah pesan (message).

Kegiatan komunikasi bagi diri manusia, akan merupakan bagian yang hakiki dalam kehidupannya. Dinamika kehidupan masyarakat akan senantiasa bersumber dari kegiatan komunikasi dan interaksi dalam hubungannya dengan pihak lain dan kelompok. ${ }^{19}$

\footnotetext{
${ }^{17}$ Departemen Agama RI Direktorat Jenderal Kelembagaan Agama Islam. Pondok Pesantren dan Madrasah Diniyah Pertumbuhan dan Perkembangannya. (Jakarta: Departemen Agama RI). Hal 37

${ }^{18}$ Soetomo. Dasar-dasar Interaksi belajar Mengajar. (Surabaya: Usana Offset Printing). 1993 Hal 75

${ }^{19}$ Sardiman A.M. Interaksi dan Motivasi Belajar Mengajar. (Jakarta: CV. Rajawali). 1986. Hal 7
} 
Dilihat dari istilah, komunikasi yang berpangkal pada perkataan communicare berarti "berpartisipasi", "memberitahukan", "menjadi milik bersama". Dengan demikian secara konseptual arti komunikasi itu sendiri sudah mengandung pengertian-pengertian memberitahukan (dan menyebarkan) berita, pengetahuan, fikiran-fikiran, nilai-nilai dengan maksud untuk menggugah partisipasi agar hal-hal yang diberitahukan itu menjadi milik bersama. Jelaslah tujuan dari komunikasi dan interaksi, sebenarnya untuk mencapai pengertian bersama, sesudah itu mencapai persetujuan mengenai sesuatu pokok ataupun masalah yang merupakan kepentingan bersama. Kalau dihubungkan dengan istilah interaksi edukatif sebenarnya komunikasi timbal balik antara pihak yang satu dengan pihak yang lain, sudah mengandung maksud-maksud tertentu, yakni untuk mencapai pengertian bersama yang kemudian untuk mencapai tujuan (dalam kegiatan belajar berarti untuk mencapai tujuan belajar). Interaksi yang dikatakan sebagai interaksi edukatif, apabila secara sadar mempunyai tujuan untuk mendidik, untuk mengantarkan anak didik kearah "kedewasaannya" ${ }^{20}$

Dalam interaksi edukatif yang sering juga disebut dengan interaksi belajar mengajar, di dalamnya pasti terkandung 2 unsur pokok yaitu unsur kegiatan guru dan unsur kegiatan murid. Sehingga apa yang dilakukan oleh guru mendapat respon dari murid, dan demikian pula sebaliknya apa yang dilakukan murid akan mendapat sambutan dari para guru. Semua kegiatan tersebut diikhtisarkan dengan beberapa ciri-ciri interaksi edukatif. ${ }^{21}$ Adapun ciri-ciri interaksi dalam pembelajaran, yaitu: ada tujuan yang ingin dicapai, ada bahan atau pesan yang menjadi isi interaksi, ada pelajara yang aktif mengalami, ada guru yang melaksanakan, ada metode untuk mencapai tujuan, ada situasi yang memungkinkan proses belajar-mengajar berjalan dengan baik, ada penilaian terhadap hasil interaksi. ${ }^{22}$

Dari penjelasan ciri-ciri interaksi pembelajaran diatas memiliki sedikit perbedaan dan persamaan dengan pemikiran Edi Suardi dalam bukunya Pedagogik. Edi Suardi merinci ciri-ciri interaksi belajar mengajar yaitu:

${ }^{20}$ S.B. Djamarah. Guru dan Anak Didik Dalam Interaksi Edukatif. Jakarta: Rineka Cipta. 2000 Hal 8

${ }^{21}$ M.Ainul K. 2011. Interaksi Edukatif Antara Guru Dan Anak Didik (Analisis SuratLuqman Ayat 12-19). Program Studi Pendidikan Agama Islam Jurusan PAI Fakultas Tarbiyah Universitas Islam Negeri Malang. Hal 16

${ }^{22}$ Sardiman A.M. Interaksi dan Motivasi Belajar Mengajar. (Jakarta: CV. Rajawali). 1986. Hal 13 
1. Interaksi belajar mengajar memiliki tujuan, yakni untuk membantu anak dalam suatu perkembangan tertentu.

2. Ada suatu prosedur (jalannya interaksi) yang direncanakan, di disain untuk mencapai tujuan yang telah ditetapkan.

3. Interaksi belajar-mengajar ditandai dengan suatu penggarapan materi yang khusus.

Dalam hal ini materi harus didisain sedemikian rupa sehingga cocok untuk mencapai tujuan.

4. Ditandai dengan adanya aktifitas siswa.

Sebagai konsekuensi, bahwa siswa merupakan sentral, maka aktifitas siswa merupakan syarat mutlak bagi berlangsungnya interaksi belajar mengajar.

5. Dalam interaksi belajar mengajar, guru berperan sebagai pembimbing.

Dalam perannya sebagai pembimbing ini guru harus berusaha menghidupkan dan memberikan motivasi, agar terjadi proses interaksi yang kondusif.

6. Di dalam interaksi belajar mengajar membutuhkan disiplin.

Disiplin dalam interaksi belajar mengajar ini diartikan sebagai sesuatu pola tingkah laku yang diatur sedemikian rupa menurut ketentuan yang sudah ditaati oleh semua pihak dengan secara sadar, baik pihak guru maupun pihak siswa.

7. Ada batas waktu, untuk mencapai tujuan pembelajaran tertentu dalam sistem berkelas (kelompok siswa), batas waktu menjadi salah satu ciri yang tidak bisa ditinggalkan. ${ }^{23}$

Peranan guru sangat diperlukan tugas seorang guru ialah mengajar, dimana guru harus membimbing anak belajar, dengan menyediakan situasi kondisi yang tepat, agar potensi anak dapat berkembang semaksimal mungkin. Dengan demikian diharapkan tujuan pendidikan dapat tercapai. Mengajar hanya membantu siswa beajar, ialah menyediakan situasi kondisi yang tepat agar siswa dapat belajar.

Siswa tidak sekedar sebagai obyek saja, tetapi terutama sebagai subyek yang belajar. Agar hasil belajar seoptimal mungkin, maka kegiatan belajar ini harus direncanakan. Dengan kata lain seorang guru harus merencanakan proses belajar dimana terjadi dengan adanya interaksi belajar

${ }^{23}$ Soetomo. Dasar-dasar Interaksi belajar Mengajar. (Surabaya: Usana Offset Printing). 1993. Hal 16 
mengajar. Guru harus dapat memilih bentuk ineraksi belajar mengajar yang mana yang tepat, serta apa saja yang harus dipertimbangkan dalam menentukan pemilihan interaksi tersebut. Agar terjadi interaksi belajar mengajar yang baik. ${ }^{24}$ Adapun kedudukan guru dalam interaksi belajar mengajar ialah: berfungsi sebagai pengajar; berfungsi sebagai pemimpin; berfungsi sebagai pengganti orang tua.

Sebagai pengajar seorang guru diharapkan menyediakan situasi dan kondisi belajar, untuk siswa di dalam interaksi belajar mengajar. Maksudnya menyediakan segala sesuatu yang dibutuhkan siswa dalam belajar, berupa: pengetahuan, sikap, ketrampilan, sarana maupun prasarana serta fasilitas material. Seorang guru berfungsi sebagai pemimpin, ialah sebagai pemimpin yang demokratis. Sifat itu sangat diharapkan bagi seorang guru, hal mana ia akan bersifat terbuka, mau mendengarkan pendapat orang lain, keluhan, pikiran, perasaan, ide muridnya, serta bersedia bekerja sama, saling mengerti dan toleransi. ${ }^{25}$

Dalam interaksi edukatif unsur guru dan anak didik harus aktif, tidak mungkin terjadi proses interaksi eukatif bila hanya satu unsur yang aktif, aktif dalam arti sikap, mental dan perbuatan. Dalam sistem pengajaran dengan pendekatan keterampilan proses, anak didik harus lebih aktif daripada guru, guru hanya bertindak sebagai pembimbing dan fasilitator. Dalam interaksi edukatif yang sering juga disebut dengan interaksi belajar mengajar, di dalamnya pasti terkandung 2 unsur pokok yaitu unsur kegiatan guru dan unsur kegiatan murid, sehingga apa yang dilakukan oleh guru mendapat respon dari murid, dan demikian pula sebaliknya apa yang dilakukan murid akan mendapat sambutan dari para guru. Semua kegiatan tersebut diikhtisarkan dengan beberapa ciri-ciri interaksi edukatif. ${ }^{26}$ Adapun ciri-ciri interaksi dalam pembelajaran, yaitu: 1) ada tujuan yang ingin dicapai; 2) ada bahan atau pesan yang menjadi isi interaksi; 3) ada pelajara yang aktif mengalami; 3) ada guru yang melaksanakan; 4) ada metode untuk mencapai tujuan; 5) ada situasi yang memungkinkan proses belajar-mengajar berjalan dengan baik; 6) ada penilaian terhadap hasil interaksi. ${ }^{27}$

\footnotetext{
${ }^{24}$ Sardiman A.M. Interaksi dan Motivasi Belajar Mengajar. (Jakarta: CV. Rajawali). 1986.. Hal 44

${ }^{25}$ Soetomo, Dasar..... Hal 45

26 M. Ainul K. 2011. Interaksi Edukatif Antara Guru Dan Anak Didik (Analisis SuratLuqman Ayat 12-19). Program Studi Pendidikan Agama Islam Jurusan PAI Universitas Islam Negeri Malang. Hal 16

${ }^{27}$ Sardiman A.M. Interaksi.... Hal 13
} 
Dari penjelasan ciri-ciri interaksi pembelajaran diatas memiliki sedikit perbedaan dan persamaan dengan pemikiran Edi Suardi dalam bukunya Pedagogik. Edi Suardi merinci ciri-ciri interaksi belajar mengajar yaitu:

1. Interaksi belajar mengajar memiliki tujuan, yakni untuk membantu anak dalam suatu perkembangan tertentu.

2. Ada suatu prosedur (jalannya interaksi) yang direncanakan, di disain untuk mencapai tujuan yang telah ditetapkan.

3. Interaksi belajar-mengajar ditandai dengan suatu penggarapan materi yang khusus.

Dalam hal ini materi harus didisain sedemikian rupa sehingga cocok untuk mencapai tujuan.

8. Ditandai dengan adanya aktifitas siswa.

Sebagai konsekuensi, bahwa siswa merupakan sentral, maka aktifitas siswa merupakan syarat mutlak bagi berlangsungnya interaksi belajar mengajar.

9. Dalam interaksi belajar mengajar, guru berperan sebagai pembimbing.

Dalam perannya sebagai pembimbing ini guru harus berusaha menghidupkan dan memberikan motivasi, agar terjadi proses interaksi yang kondusif.

10. Di dalam interaksi belajar mengajar membutuhkan disiplin.

Disiplin dalam interaksi belajar mengajar ini diartikan sebagai sesuatu pola tingkah laku yang diatur sedemikian rupa menurut ketentuan yang sudah ditaati oleh semua pihak dengan secara sadar, baik pihak guru maupun pihak siswa.

11. Ada batas waktu

Untuk mencapai tujuan pembelajaran tertentu dalam sistem berkelas (kelompok siswa), batas waktu menjadi salah satu ciri yang tidak bisa ditinggalkan. $^{28}$

Peranan guru sangat diperlukan tugas seorang guru ialah mengajar, dimana guru harus membimbing anak belajar, dengan menyediakan situasi kondisi yang tepat, agar potensi anak dapat berkembang semaksimal mungkin. Dengan demikian diharapkan tujuan pendidikan dapat tercapai.

\footnotetext{
${ }^{28}$ Soetomo. Dasar-dasar Interaksi belajar Mengajar. (Surabaya: Usana Offset Printing). Hal 16
} 
Mengajar hanya membantu siswa beajar, ialah menyediakan situasi kondisi yang tepat agar siswa dapat belajar.

Siswa tidak sekedar sebagai obyek saja, tetapi terutama sebagai subyek yang belajar. Agar hasil belajar seoptimal mungkin, maka kegiatan belajar ini harus direncanakan. Dengan kata lain seorang guru harus merencanakan proses belajar dimana terjadi dengan adanya interaksi belajar mengajar. Guru harus dapat memilih bentuk ineraksi belajar mengajar yang mana yang tepat, serta apa saja yang harus dipertimbangkan dalam menentukan pemilihan interaksi tersebut. Agar terjadi interaksi belajar mengajar yang baik. ${ }^{29}$ Adapun kedudukan guru dalam interaksi belajar mengajar ialah: 1) berfungsi sebagai pengajar; 2) berfungsi sebagai pemimpin; 3) berfungsi sebagai pengganti orang tua.

Sebagai pengajar seorang guru diharapkan menyediakan situasi dan kondisi belajar, untuk siswa di dalam interaksi belajar mengajar. Maksudnya menyediakan segala sesuatu yang dibutuhkan siswa dalam belajar, berupa: pengetahuan, sikap, ketrampilan, sarana maupun prasarana serta fasilitas material. Seorang guru berfungsi sebagai pemimpin, ialah sebagai pemimpin yang demokratis. Sifat itu sangat diharapkan bagi seorang guru, hal mana ia akan bersifat terbuka, mau mendengarkan pendapat orang lain, keluhan, pikiran, perasaan, ide muridnya, serta bersedia bekerja sama, saling mengerti dan toleransi. ${ }^{30}$

Ada tiga pola komunikasi antara guru dan anak didik dalam proses interkatif edukatif, yakni komunikasi sebagai aksi, komunikasi sebagai interaksi, dan komunikasi sebagai transaksi. Dalam komunikasi sebagai interaksi atau komunikasi dua arah guru berperan sebagai pemberi aksi atau penerima aksi. Demikian juga halnya anak didik, bisa sebagai penerima aksi, bisa pula sebagai pemberi aksi. Antara guru dan anak didik akan terjadi dialog. ${ }^{31}$ Dalam interaksi guru dan murid di lingkungan pesantren, sedikit persamaan dengan sekolah umum. Namun yang membedakannya ialah nilainilai kultural-moral.

${ }^{29}$ S. Adisusilo. Pembelajaran Nilai Karakter: Kontruktivisme dan VCT Sebagai Inovasi Pendekatan Pembelajaran Afektif. Jakarta: PT Raja Grafindo Persada. 2012. Hal 44

${ }^{30}$ Adisusulo. Pembelajaran.... Hal 45

${ }^{31}$ Syaiful Bahri Djamarah.2000. Guru dan Anak Didik Dalam Interaksi Edukatif. (Jakarta: Rineka Cipta), Hal 12 


\section{METODE PENELITIAN}

Metode penelitian yang di gunakan dalam penulisan ini yaitu studi kepustakaan (library research). Data yang di dapat yang pertama, dari sumber data primer yang berupa novel dengan judul "Love In Pesantren" karya Shachree M. Daroini dan yang kedua, sumber data sekunder yang berupa buku-buku pendukung dan jurnal hasil penelitian terdahulu. Adapun langkah-langkah pengumpulan data antara lain: 1) teknik pustaka, 2) teknik simak, 3) teknik catat. Dari langkah-langkah tersebut akan diperoleh data berupa: 1) paparan bahasa yang mengandung nilai-nilai edukatif; 2) paparan bahasa yang mengemban nilai-nilai edukatif yang mendeskripsikan pola interaksi guru dan murid di lingkungan pesantren; dan 3) bahan untuk mengadakan reformulasi pola interaksi guru dan murid di lingkungan pesantren berdasarkan novel "Love In Pesantren". Langkah berikutnya dilakukanlah analisis isi (Content Analysis) mendapatkan objektivitas isi, pendekatan secara sistematis dan generalisasi, sehingga dapat diidentifikasi nilai-nilai edukatif yang ada; dan identifikasi hal-hal yang kurang relevan terkait interaksi guru dan murid di Pesantren; serta identifikasi pola interaksi guru dan murid sebagai reformulasi interaksi di Pesantren

\section{PEMBAHASAN}

Nilai-nilai edukatif dalam novel "Love In Pesantren" ini didalamnya mencakup sikap individu dalam kehidupan pribadi, kehidupan sosial, dan kehidupan yang berhubungan dengan Tuhan. terdiri beberapa nilai, diantaranya:

1. Nilai Keimanan dan Ketaqwaan

Keimanan dan ketaqwaan merupakan kunci kehidupan yang harus di miliki setiap manusia. Dimana keimanan dan ketaqwaan bisa saja berkurang dan bertambah, maka dari itu harus ada upaya untuk senantiasa meningkatkan keimanan dan ketaqwaan, dengan adanya ilmu manusia bisa memperkuat keimanan dan ketaqwaan, apabila ilmu bertambah maka keimanan dan ketaqwaan manusia bertambah.

2. Tolong Menolong

Manusia hidup tidak dengan sendirinya. Dimana seseorang tidak bisa hidup tanpa bantuan orang lain. Dengan saling tolong menolong kehidupan akan membuahkan sifat terpuji dan kehidupan akan lebih berarti, tanggap pada persoalan dan kesulitan orang lain akan membuahkan sikap tolong menolong. 
3. Semangat Melaksanakan Ritual Keagamaan

Semangat melakukan ritual keagamaan akan memupuk keimanan dan ketaqwaan yang akan menjadikan jiwa yang sholeh, sholihah. Tidak hanya jiwa muda dan sehat saja, namun juga dalam semua keadaan seperti yang dicontohkan oleh seorang kyai, dalam semangat ritual keagamaan tidak mengenal usia ataupun kondisi. Kesepuhan dan keadaan Kiai Mail tidak membuat menyerah untuk menjadi imam sholat berjama'ah bersama para santri, dimana Kiai Mail mengajarkan sholat tepat waktu dan secara berjama'ah kepada santrinya.

4. Menyadari Keterbatasan Diri

Yang dimaksud dalam menyadari keterbatasan diri adalah kelemahan dan kekurangan diri sendiri. Dengan mengakui keterbatasan diri akan terhindar dari kesombongan, namun tidak menjadikan berkecil hati, sikap menyadari keterbatasan diri akan menyadarkan diri sendiri, tidak merasa paling baik dibandingkan dengan manusia lain. Tetapi dengan sikap ini tidak membuat orang untuk berputus asa.

5. Mampu Menerima Perubahan

Membuka diri untuk perubahan menuju arah lebih baik itu perlu. Perubahanlah yang akan membuat kehidupan juga berubah., adanya perubahan dari pesantren yang awalnya salaf, pesantren tersebut mendirikan sekolah formal yang bernaung di wilayah pondok pesantren. Mekipun adanya pendidikan formal, tidak menghapus kesalafan dari pondok pesantren, hanya saja diberi kelas untuk belajar dan sekolah formal setingkat sekolah formal di luar pondok pada umumnya. Dialog, sebagai generasi muslim juga harus bisa berubah sesuai zamannya. Dengan banyaknya budaya barat yang masuk di bangsa ini, sebagai generasi Islam harus menguasai kemajuan zaman yang modern dan bisa bertarung dengan kebudayaan barat.

6. Amar Ma'ruf Nahi Munkar

Semua orang pasti pernah melakukan kesalahan dan kadang ia tidak atau belum menyadari kesalahannya. Karena itu, ia butuh saran dan kritik dari orang lain, nasihat atau mauidhoh khasanah unutk memperbaiki kesalahan. Kegiatan dalam rangka menyuruh kepada kebaikan dan mencegah dari kemungkaran inilah yang dikenal dengan istilah amar ma'ruf nahi munkar. Keamanan itu akan membangunkan para santri tiga tahap, pertama, sebelum subuh untuk melatih para santri bangun malam dan menunaikan shalat malam, kedua, menjelang azan subuh agar para santri terbiasa melaksanakan shalat tepat pada waktunya, ketiga, usai shalat subuh 
keamanan akan beroperasi kembali membangunkan mereka yang belum shalat. Selain agar mereka tidak meninggalkan kewajiban shalat, juga karena kegiatan pondok, seperti mengaji kitab kuning atau mengaji kitab suci AlQur'an sudah siap dimulai. ${ }^{32}$ Amar Ma'ruf Nahi Munkar yakni menyuruh kepada kebaikan dan mencegah kemunkaran. Kedua narasi di atas menunjukkan bahwa dalam rangka amar ma'ruf nahi munkar diperlukan metode yang tepat. Dalam dialog menggunakan mauidhoh hasanah, sedang dalam narasi menggunakan tindakan langsung.

7. Kemandirian

Sikap mandiri merupakan sikap yang positif yang harus dimiliki seseorang untuk kemajuan pada dirinya. Dimana mandiri merupakan keadaan yang dapat berdiri sendiri tanpa bantuan orang lain. ${ }^{33}$ Sangat penting untuk di aplikasikan dalam kehidupan sehari-hari. Sikap mandiri yang tinggi akan menumbuhkan sikap juang yang tinggi, pantang menyerah, tidak merepotkan orang lain, tidak tergantung pada orang lain. Dari narasi di atas Kiai Mail bisa jadi contoh para santri, guru, maupun masyarakat untuk bisa menjadi mandiri.

8. Prinsip Keadilan

Dalam novel "Love In Pesantren" ini banyak prinsip keadilan. Terutama dalam hal menjatuhkan hukuman. Namun keadilan yang sesungguhnya tidak hanya menjatuhkan hukuman, tetapi juga keadilan dalam tanggung jawab dan hak, karena semua membutuhkan keadilan. ${ }^{34}$ Sikap tidak adil dan semena-mena akan menimbulkan sifat dendam. Maka dari itu sikap adil itu harus. Dalam memberi hukuman terhadap murid pun juga harus adil tidak boleh sepihak dengan tidak adil.

9. Menghargai dan Menghormati Sesama Manusia

Tak ada seorang pun yang tak ingin dihormati dan dihargai. Penghormatan dan penghargaan itupun bukan hanya milik para orang tua, konglomerat atau pejabat, melainkan milik semua orang. Karenanya, apabila seseorang merasa direndahkan, dilecehkan, tentu ia akan merasa tersinggung. Oleh karenanya, novel ini pun tak luput dari nilai edukatif ini, menghargai

\footnotetext{
${ }^{32}$ A. Z. Arifin. Reinventing Human Caracter: Pendidikan Karakter Berbasis Nilai \& Etika di Sekolah. Jogjakarta: AR-Ruzz Media. 2012. Hal. 22

${ }^{33}$ S. Adisusilo. Pembelajaran Nilai Karakter: Kontruktivisme dan VCT Sebagai Inovasi Pendekatan Pembelajaran Afektif. Jakarta: PT Raja Grafindo Persada. 2012. Hal 44

${ }^{34}$ Ainul. Interaksi Edukatif Antara Guru Dan Anak Didik (Analisis Surat Luqman Ayat 12 19). Malang: UIN. 2011. Hal. 61:4
} 
dan menghormati sesama manusia merupakan prinsip utama dalam berinteraksi. Penghargaan dan penghormatan layak di miliki setiap orang, di mana orang yang menghargai dan menghormati orang lain juga akan di hargai dan di hormati pula.

10. Berfikir Kritis Mengenai Kehidupan

Berfikir kritis merupakan sebuah keharusan. Karena dengan berfikir kritis seseorang akan menemukan kebenaran dengan cara yang masuk akal atau logis. Dari sinilah dapat diketahui betapa pentingnya dalam berfikir kritis bagi kehidupan. Kritis merupakan ciri khas intelek. Bersikap kritis terhadap kehidupan adalah sikap positif yang harus dikembangkan. Berfikir kritis mutlak diperlukan agar manusia mampu menggali ilmu Allah secara komprehensif dan mendalam. Tanpa bersikap kritis terhadap fenomena, manusia akan stagnan dan tidak mengalami perbaikan keadaan.

\section{Mau Memaafkan}

Memaafkan adalah sifat terpuji. Manusia memiliki keterbatasan dan tak luput dari kesalahan, karena tidak ada manusia yang sempurna. Manusia pasti pernah melakukan kesalahan yang disengaja maupun tidak disengaja. Hanya saja apakah manusia itu menyadari dari kesalahan yang telah dibuat dan bisa memberi maaf terhadap kesalahan orang lain.

Sikap tak mau memaafkan kesalahan yang sebenarnya tidak prinsipil, sedang yang melakukan kesalahan telah diganjar oleh hukuman, hanya akan menyisakan sakit hati, bahkan dendam, sikap tidak mau memaafkan bisa menimbulkan kebencian terhadap orang lain. Hal ini yang tergambar dalam narasi, oleh karena itulah apabila kesalahan yang dilakukan bukan pada halhal prinsip akan lebih baik jika seseorang mau membuka hatinya untuk memaafkan orang lain. Sedang dalam dialog menunjukkan tentang keluasan hati seorang istri untuk memaafkan kesalahan suaminya.

Berdasarkan bacaan, refleksi dan analisis dalam novel "Love In Pesantren", terdapat hal-hal yang kurang relevan untuk diterapkan dalam Pesantren Abu Darda' yang terkait dengan interaksi antara guru dan murid. Hal ini ditandai dengan kurangnya keharmonisan hubungan antara guru dan murid. ${ }^{35}$ Hal ini juga tidak relevan apabila diterapkan dalam dunia pendidikan, yakni:

\footnotetext{
35 S. Adisusilo. Pembelajaran Nilai Karakter: Kontruktivisme dan VCT Sebagai Inovasi
} Pendekatan Pembelajaran Afektif. Jakarta: PT Raja Grafindo Persada. 2012. Hal 44 


\section{Pemberian Hukuman Fisik Diluar Kadar Kemampuan}

Pemberian hukuman yang tidak sesuai kemampuan menyebabkan murid akan trauma bahkan bisa saja jiwanya terganggu atas hukuman yang telah diberikan oleh guru itu melampaui batas. Padahal, andaikan hukuman itu dimaksudkan untuk memberikan pelajaran seharusnya dilakukan dengan prosedur dan metode yang sekiranya mampu menimbulkan kesadaran siswa bukannya memicu masalah baru, dampak jangka panjangnya, seorang murid akan cenderung melakukan perbuatan yang sama di masa mendatang.

2. Sikap Yang Tidak Berkasih Sayang

Guru merupakan orang tua kedua yang ada di sekolah. Sebagai orang tua harus menyayangi dan mengasihi anaknya. Begitu juga dengan guru dimana guru seharusnya menyayangi muridnya dengan tulus, di didik dengan baik penuh kasih sayang, sehingga dengan begitu interaksi akan terasa harmonis dan pembelajaran murid akan mudah dilakukan.

3. Tidak Menghargai Murid

Sikap orang lain sering kali merupakan pencerminan dari sikap kita pada mereka apalagi guru yang menjadi cerminan muridnya. Murid juga manusia yang layak memperoleh penghargaan dan penghormatan. Jika murid di didik tanpa penghargaan, maka ia akan menjadi manusia dewasa yang juga tak bisa menghargai orang lain akibat didikan yang demikian.

4. Memperlakukan Murid Seenaknya Sendiri

Jika guru memperlakukan murid seenaknya sendiri, bisa jadi murid akan meniru guru, karena guru adalah yang ditiru muridnya. Jika ada masalah pada murid setidaknya guru memecahkan masalahnya dengan baik tanpa ada yang dirugikan.

5. Tidak memberikan kesempatan kepada murid untuk membela diri

Setiap manusia berhak untuk mengutarakan pendapat baik secara lisan maupun tulisan, setiap manusia berhak melakukan pembelaan terhadap dirinya sendiri atau orang lain. Karena memang, tanpa sikap ini, guru menjadi sosok yang otoriter dan senantiasa merasa dialah yang paling benar. Akibatnya, murid hanya menjadi manusia yang tidak bisa membela dirinya sendiri, pasif dan pasrah.

6. Tidak Memanusiakan Murid

Salah satu tujuan pendidikan yaitu memanusiakan manusia. Pendidikan adalah lembaga yang mengajarkan banyak ilmu, mengajarkan kebaikan, mendidik untuk menjadi manusia yang sesungguhnya yaitu menjadi manusia yang lebih baik. Maka tidak layaklah apabila guru tidak 


\section{4 ][ Analisis Nilai-Nilai Edukatif Dalam Novel "Love In Pesantren”}

memanusiakan muridnya, dimana murid yang masih butuh bimbingan seorang guru untuk bisa merubah dirinya menjadi lebih baik dan bangkit dari keburukan.

7. Sikap otoriter

Sikap otoriter akan melahirkan generasi otoritarian. Bahwa apapun yang dilakukan, diajarkan, ditampakkan, diucapkan guru merupakan sesuatu yang akan ditiru oleh muridnya, merupakan dasar dalam analisa ini.

8. Mengandalkan nalar kritis atas dasar keta'dziman

Memenggal rasa ingin tahu, tidak membuka ruang sharing dan diskusi lalu mengatas namakan keta'dziman dan barokah sebagai justifikasi, hanya akan melahirkan generasi yang tak berkualitas dan eksklusif terhadap satu pandangan sempit serta menjadi sosok yang kurang toleran terhadap perbedaan. Dari sinilah bisa diketahui bahwa berfikir kritis itu perlu.

Berdasarkan uraian dan analisis mengenai nilai edukatif yang ada dalam novel "Love In Pesantren", kemudian menganalisis hal-hal yang kurang relevan dalam menerapkan interaksi guru dan murid, maka tibalah saatnya untuk memberikan sebuah penjelasan konsep mengenai upaya pencegahan dan penanggulangan dampak negatif akibat interaksi yang kurang harmonis.

Reformulasi yang penulis jelaskan bisa jadi telah ada dan diaplikasikan dalam realitas pesantren dengan tingkat pengaplikasian yang beragam. Namun peneguhan dan pengukuhan nilai-nilai yang akan penulis paparkan dirasa perlu akibat masih berkembangnya nilai-nilai yang kurang relevan tersebut di pesantren. ${ }^{36}$

Dari beragam nilai yang telah dipaparkan pada pembahasan sebelumnya, maka yang dapat ditarik sebagai sebuah pijakan untuk melakukan pembaruan dalam menyikapi pola interaksi guru dan murid di lingkungan pesantren adalah sebagai berikut: ${ }^{37}$

1. Saling menghormati antara guru dan murid. Murid percaya bahwa dirinya tidak akan menjadi orang baik dan pandai tanpa guru, dan guru dalam melaksanakan tugasnya dirasakan sebagai mengemban amanat Tuhan dan mendidik murid menjadi lebih baik.

\footnotetext{
${ }^{36}$ Mansur.Moralitas Pesantren:Meneguk Kearifan dari Telaga Kehidupan. Yogyakarta: Safira Insania Press. 2014

37 Soetomo. Dasar-dasar Interaksi belajar Mengajar. (Surabaya: Usana Offset Printing). 1993. Hal 16
} 
2. Penghargaan terhadap perbedaan, bahwa baik guru maupun murid harus memahami bahwa setiap manusia itu berbeda, baik karakter, kecenderungan, dan sebagainya.

3. Prinsip keadilan, seorang guru harus bisa menempatkan diri sebagai pengajar yang adil dan tidak sewenang-wenang serta tidak pilih kasih terhadap muridnya.

4. Saling memaafkan, setiap orang pernah melakukan kesalahan, oleh karena itulah baik guru dan murid harus memahami diri maupun orang lain tentu tak pernah luput dari salah. Sehingga setiap kesalahan dan ketidak nyamanan haruslah diselesaikan dengan terbuka agar tercipta ketulusan saling memaafkan, dengan memaafkan interaksi akan berjalan secara baik.

5. Tidak merasa dirinya yang paling benar, kadang ego manusia menghendaki dirinya selalu benar dan diakui kebenarannya oleh orang lain. Padahal, tak jarang manusia yang paling pintar dan alim sekalipun melakukan kesalahan yang fatal. Oleh karena itulah, perlunya kesadaran diri dari masing-masing guru dan murid untuk memahami kelemahan diri agar tidak ada yang merasa dirinya paling benar.

6. Saling terbuka, salah satu cara untuk melakukan interaksi yang baik antara guru dan murid. Dengan saling terbuka akan terjalin interkasi yang harmonis.

\section{KESIMPULAN}

1. Nilai-niali edukatif dalam novel "Love In Pesantren", sebagai berikut: a) Meningkatkan keimanan dan ketaqwaan; b) Tolong menolong; c) Semangat melakukan ritual keagamaan; d) Menyadari keterbatasan diri; e) Mampu menerima perubahan; f) Amar ma'ruf nahi munkar; g) Kemandirian; h) Prinsip keadilan; i) Menghargai dan menghormati sesame manusia; j) Berfikir kritis mengenai kehidupan; k) Mau memaafkan.

2. Hal-hal yang kurang relevan terkait pola interaksi guru dan murid di pesantren dalam novel "Love In Pesantren", sebagai berikut: a) Pemberian hukuman fisik diluar kadar kemampuan; b) Sikap yang tidak berkasih sayang; c) Tidak menghargai murid; d) Memperlakukan murid seenaknya sendiri: e) Tidak memberikan kesempatan kepada murid untuk membela diri; f) Tidak memanusiakan murid; g) Sikap otoriter; h) Mengandalkan nalar kritis atas dasar keta'dziman 
3. Pola interaksi guru dan murid sebagai reformulasi interaksi di pesantren dilakukan dengan cara: a) Saling menghormati antara guru dan murid; b) Penghargaan terhadap perbedaan; c) Prinsip keadilan; d) Saling memaafkan; e) Tidak merasa dirinya yang paling benar; f) Saling terbuka

\section{DAFTAR PUSTAKA}

Adisusilo S. 2012. Pembelajaran Nilai Karakter: Kontruktivisme dan VCT Sebagai Inovasi Pendekatan Pembelajaran Afektif. Jakarta: PT RajaGrafindo Persada.

Ainul M.K. 2011. Interaksi Edukatif Antara Guru Dan Anak Didik (Analisis SuratLuqman Ayat 12-19). Malang: UIN.

Arifin A.Z. 2012. Reinventing Human Caracter: Pendidikan Karakter Berbasis Nilai \& Etika di Sekolah. Jogjakarta: AR-Ruzz Media.

Arifin S. 2010. Analisis Komparasi Konsep Belajar Dan Pembelajaran Menurut Al-Ghazali Dan Al-Zarnuji. Pasuruan: UYP.

Daroini S.M. 2012 Love In Pesantren. Yogyakarta: PT LKis Printing Cemerlang.

Departemen Agama RI Direktorat Jenderal Kelembagaan Agama Islam. 2003. Pondok Pesantren dan Madrasah Diniyah Pertumbuhan dan Perkembangannya. Jakarta: Departemen Agama RI.

Djamarah S.B. 2000. Guru dan Anak Didik Dalam Interaksi Edukatif. Jakarta: Rineka Cipta.

Hitami M. 2004. Mengenal Kembali Pendidikan Islam. Yogyakarta: LKis Yogyakarta.

Ihsan F. 2003. Dasar-dasar Kependidikan. Jakarta: PT RINEKA CIPTA.

Mansur. 2014.Moralitas Pesantren:Meneguk Kearifan dari Telaga Kehidupan. Yogyakarta: Safira Insania Press.

Nurgiyanto B. 2005. Teori Pengkajian Fiksi. Yogyakarta: UGM.

Sardiman A.M. 1986. Interaksi dan Motivasi Belajar Mengajar. Jakarta: CV. Rajawali.

Soetomo. 1993. Dasar-dasar Interaksi belajar Mengajar. (Surabaya: Usana Offset Printing.

Suharto B. 2011. Dari Pesantren Untuk Umat: Reinventing Eksistensi Pesantren di Era Glogalisasi. Surabaya: IMTIYAZ.

Undang-Undang Republik Indonesia No 20 Tahun 2003 tentang Sistem Pendidikan Nasional (SISDIKNAS). 
Achmat Mubarok, Asrul Anan ][ 237

Yasmadi. 2002. Modernisasi Pesantren: Kritik Nurcholis Madjid Terhadap Pendidikan Islam Tradisional. Jakarta: Ciputat Press.

Nurnal al-Murabli, Volume 4 Namar 2, Jumi 2019 
238 ][ Analisis Nilai-Nilai Edukatif Dalam Novel "Love In Pesantren"

Nurnal al-Murabli, Volume 4 Namar 2, Jumi 2019 